\title{
ATTRIBUTES IN UTILIZATION OF DAIRYING INFORMATION AMONG TRIBAL AND NON-TRIBAL DAIRY FARMERS IN CACHAR DISTRICT OF ASSAM
}

\section{SANATHOI KHUMAN ${ }^{1}$, GAUTAM BORDOLOI ${ }^{2}$, SANJIB BORAH ${ }^{3}$, PRASANTA CHABUKDHARA ${ }^{4}$, SIDDHARTHA SANKAR PATHAK ${ }^{5} \&$ PRASANTA KUMAR BORO $^{6}$}

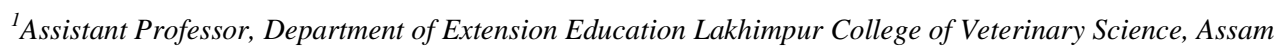
Agricultural University, Joyhing, North Lakhimpur, Assam, India

${ }^{2}$ Assistant Professor, Department of Parasitology Lakhimpur College of Veterinary Science, Assam Agricultural University, Joyhing, North Lakhimpur, Assam, India

3, ${ }^{4}$ Assistant Professor, Department of Physiology \& Biochemistry Lakhimpur College of Veterinary Science, Assam Agricultural University, Joyhing, North Lakhimpur, Assam, India

${ }^{5}$ Assistant Professor, Department of LPM Lakhimpur College of Veterinary Science, Assam Agricultural University, Joyhing, North Lakhimpur, Assam, India

${ }^{6}$ Assistant Professor, Department of Preventive Medicine, Lakhimpur College of Veterinary Science, Assam Agricultural University, Joyhing, North Lakhimpur, Assam, India

ABSTRACT
Information seeking and utilization pattern among tribal and non-tribal farmers are believed to be different on
account of many factors, including their different milk consumption habits. An investigation among the tribal and non-
tribal dairy farmers in four development blocks of Cachar district of Assam revealed that, among tribal farmers age,
family size, herd size, farm size, milk production, milk disposal, milk consumption, annual family income, annual family
income from dairying, social participation, attitude towards dairy farming, economic motivation, source of motivation for
dairy communication, and extension contact had positive and significant relationship with utilization of information,
while in case of non-tribal dairy farmers age, herd size, farm size, milk production, milk disposal, milk consumption,
annual family income from dairying, social participation, attitude towards dairy farming, economic motivation, source of
motivation for dairy communication and extension contact had positive and significant relationship with utilization of
information. Regression analysis revealed, source of motivation for dairy communication crucially influenced utilization
of information of farmers. It gave a good signal for utilization of credible source for dissemination of information
relating to dairying, and if necessity arose, to be putting different emphasis on strategies for tribal and non-tribal farmers
for better dairying in the areas of study.
KEYWORDS- Utilization of Information, Dairying, Tribal Farmer \& Non-Tribal Farmer

Received: Apr 07, 2017; Accepted: May 06, 2017; Published: Jun 01, 2017; Paper Id.: IJESRJUN20176

\section{INTRODUCTION}

Although India has become the leading milk producer in the world, there is a huge disparity in the milk producing areas as the majority of milk come from only some distinct regions of the country. Dairy production in North-Eastern states has traditionally lagged behind when compared to major milk producing states due to its customary and traditional preference for meat. However, in recent years, it is seen that due to the introduction of many state, national and international rural development programs and projects, exposure and experiences and 
major changes in the social economic scenario; things are looking brighter for dairying. In the developing world of today, it is not the lack of technology that worries, but it is the transfer of technology from the point of production to the point of its utilization. There is an increasing gap between innovations in the laboratories and their adoption in the field. The Herculean task of bridging the ever widening gap to some parity among pockets is understandably entrusted to the extension agencies operating in the country. The bridging of this wide gap is only possible, when there is an effective transfer of the technology and its proper utilization by the farmers. For the various dairy development programs succeed it needs continued and universal participation of the farmers and their constant updating of information related to dairying. Effective communication, its utilization of different sources and channels of transmission are the essence of extension. They provide rural people maximum impetus to modify their behavior for sustainable benefits in the society. Therefore, the study was taken up to identify those characteristics carried some relation and which effected utilization of information related to dairying for strategizing a better plan for dairy development.

\section{METHODOLOGY}

The study was undertaken to know the psychological and motivational profile among 50 tribes and 50 non-tribal dairy farmers in 4 selected development blocks of Cachar District of Assam, namely Silchar, Salchapra, Borkhola and Sonai. Three villages, each for tribal and non-tribal dairy farmers staying together were randomly selected from each of the 4 blocks. A list of all the tribal and non-tribal dairy farmers having at least one milch cow/buffalo was prepared separately in consultation with the A.H. \& Vety and Dairy Development Officials of the district. A total of twenty five dairy farmers comprising of both tribal and non-tribal were selected randomly from each of the blocks so as to make 50 tribes and 50 non-tribal respondents and the sample size of 100 . Data were collected by personally interviewing the selected respondents with the reliable and valid interview schedule. Reliability of the interview schedule was worked out by the test - retest method in Karimganj district of Barak Valley and was formed to be are $=0.93$. Further, content validity was ensured while preparing the final schedule. Data were personally collected by the researcher. After collection, they were arranged and analyzed for correlation and regression coefficient and inferences were drawn accordingly.

\section{FINDINGS AND DISCUSSIONS}

Utilization of information referred to the proportion of knowledge brought to application by the respondent, after getting exposure to various sources of information related to dairying (media/agency/networks) like Television, Radio, Newspaper/ dairy magazine/ extension publication, Relatives, Friends, Veterinary officials, Meetings etc, which were considered for study in this investigation?

\section{Correlation Analysis of Socio-Personal Attributes with Utilization of Information}

Table 1 revealed that in case of tribal dairy farmers family size, herd size, annual family income were positively and significantly correlated $(\mathrm{P}<0.05)$ with utilization of information while age, farm size, average milk production, average milk disposal, average milk consumption, annual family income from dairying, social participation, attitude towards dairy farming, economic motivation, source of motivation for dairy communication and extension contact were high positively and significantly correlated $(\mathrm{P}<0.01)$ with utilization of information. In case of non-tribal dairy farmer herd size, average milk consumption and economic motivation were positively and significantly correlated $(\mathrm{P}<0.05)$ with utilization of information while age, average milk production, average milk disposal, annual family income from dairying, social participation, attitude towards dairy farming, source of motivation for dairy communication and extension contact were 


\section{Non-Tribal Dairy Farmers in Cachar District of Assam}

high positively and significantly correlated $(\mathrm{P}<0.01)$ with utilization of information. It might have been because of the fact that, with increased age comes more experience and understanding which led to further utilization of information. A family having more members could be involved in farm related activities and also getting more combined exposure of information due to which there were increased need and utilization of information. Again, farmers with more animals were more profit oriented, which led them to search for more information sources and hence increased utilization. Farmers with greater land holding were more prosperous and economically viable and therefore had increased utilization of information. The farmer having more milk production; milk disposal; milk consumption, more income and more income from dairying were economically viable and were greatly motivated for more success which led to more utilization of information. Farmers have more social participation \&extension contact obviously had more intensive utilization of information due to their extrovert nature. A farmer with positive attitude towards dairy farming due to its affinity towards new idea was definitely attracted to information related to dairying, and hence increased utilization of information. While a dairy farmer having higher economic motivation had a zeal for increasing his economic status for which he searches for more information for financial expansion, which eventually leads to better utilization of information. A highly motivated farmer due to his nature will be having healthy connection with extension agents and other sources of information, therefore the better utilization of information. Similar results were seen by Sadaqath and Mariswamy (2007) were in their study, they reported that annual income, land holding and social participation had a positive and significant relationship with exposure to radio while Jahagirdar and Balasubramanya (2010) revealed that age had a positive and significant relationship with information processing while Olaniyiet. Al. (2011) in their study reported that household size and frequency of use of sources of information had a positive and significant relationship with utilization of agricultural information. Contradictory results were seen by Aderetiet. Al. (2006) found that there were significant relationships between level of education and information utilization of the farmer.

\section{Multiple Regression of Independent with Utilization of Information}

As indicated in Table 2, out of 15 independent variables, source of motivation for dairy communication was found to have highly positive and significant contributory $(\mathrm{P}<0.01)$ on the utilization of information in case of both tribal and non-tribal dairy farmers. All the remaining variables did not contribute significantly to utilization of information. This essentially indicated the fact that the dairy farmers were in readiness to get more beneficial information so as to make their dairying more profitable. Similar finding were seen where De Raad \& Schouwenburg, 1996) discussed how decisive the motivation behind broad information seeking is for informational use and outcome while Heinström (2003) reported about the decision to seek information is dependent on motivation. A well motivated farmer will always search for ways for economic improvement for which he has frequent interaction with information sources which leads to better utilization of information. The co-efficient of multiple determination $\left(\mathrm{R}^{2}\right)$ with 15 independent variables could explain 85.90 per cent (in tribal farmers) and 84.50 per cent (in non-tribal farmers) variation in the utilization of information. The ' $F$ ' value for $\mathrm{R}(15.18, \mathrm{P}<0.01)$ in the case of tribal dairy farmers and $(12.37, \mathrm{P}<0.01)$ in case of non-tribal dairy farmers were found to be highly significant. This also indicated that there are necessities for separate strategies in prioritizing the different attributes for utilization of information relating to dairying in the case of tribal and non-tribal farmers. Nevertheless, the attributes already selected had emphatic influence. 


\section{CONCLUSIONS}

From the above study it could be concluded that age, herd size, farm size, Avg. Milk production, Avg. Milk disposal, Avg. Milk consumption, annual family income from dairying, social participation, attitude towards dairy farming, economic motivation, a source of motivation for dairy communication and extension contact were having close association with utilization of information related to dairying of the farmers. But, as far as the effects were concerned, sources of motivation for dairy communication played an important role in the utilization of information about the tribal and nontribal dairy farmers. An appropriate extension strategy, if needed differently for the tribal and non-tribal dairy farmers, therefore, might work with the farmers for the development of the dairy sector in the area.

\section{REFERENCES}

1. Adereti, F.O; Fapojuwo, O.E. and Onasanya, A.S (2006). "Information Utilization on Cocoa Production Techniques by Farmers in Oluyole Local Government Area of Oyo State, Nigeria”. European Journal of Social Sciences. [On-line]. 3(1), pp. $1-7$.

2. Available:ejournal.narotama.ac.id/files/Information\%20Utilization\%20on\%20Cocoa\%20Production\%20Techniques\%20by.doc [March 26, 2014].

3. De Raad, B. \&Schouwenburg, H. C. (1996). "Personality in learning and education: a review". European Journal of Personality, 10(5), pp. 303-336.

4. Available:http://onlinelibrary.wiley.com/doi/10.1002/\%28SICI\%291099-0984\%28199612\%2910:5\%3C303::AIDPER262\%3E3.0.CO;22/abstract;jsessionid=04E03F8A6C4948B58FAC77FE6828A47D.f04t02?deniedAccessCustomisedMes sage $=\&$ userIsAuthenticated $=$ false. $[$ March 26, 2014]

5. Heinström, J. (2003). "Five personality dimensions and their influence on information behaviour". Information Research, 9(1), pp. 9-1

6. Available: acmd615.pbworks.com/f/Fivepersonalitydimensions1.pdf[March 26, 2014].

7. Jahagirdar, K.A. and Balasubramanya, A.S. (2010). "A study on communication behaviour of extension personnel". Karnataka J. Agric. Sci. 23(2), pp. 384-385.

8. Available:http://14.139.155.167/test5/index.php/kjas/article/view/3037/3266[March 26, 2014].

9. Olaniyi, O. A.; Adebayo, O. O., \&Akintola, S. (2011). "Perception of Rural Youth and Utilization of Agricultural Information in Oyo State, Nigeria". Journal of Agriculture and Social Sciences, 7. Available: http://agris.fao.org/agrissearch/search.do?f=2012/PK/PK1202.xml;PK2012000195[March 26, 2014].

10. Sadaqath, S., \&Mariswamy, H. K. (2007). "Analysis of usefulness and credibility of radio as perceived by literate farmers". Karnataka Journal of Agricultural Sciences, $20(4), \quad$ pp. $784 . \quad$ Available: http://14.139.155.167/test5/index.php/kjas/article/view/1060/1053[March 26, 2014]. 


\section{APPENDICES}

Table 1: Correlation Analysis between Independent and Utilization of Information

\begin{tabular}{|c|c|c|c|}
\hline Sl. No. & Independent Variables & Tribal ('R' Value) & Non-Tribal ('R' Value) \\
\hline 1. & Age & $0.50555 * *$ & $0.44145 * *$ \\
\hline 2. & Family size & $0.35307 *$ & $0.20692^{\mathrm{NS}}$ \\
\hline 3. & Educational status & $-0.18522^{\mathrm{NS}}$ & $0.15223^{\mathrm{NS}}$ \\
\hline 4. & Herd size & $0.35246 *$ & $0.20010 *$ \\
\hline 5. & Farm size & $0.67012 * *$ & $0.35582 *$ \\
\hline 6. & Avg. milk prod. & $0.63973 * *$ & $0.46957 * *$ \\
\hline 7. & Avg. milk disposal & $0.62026 * *$ & $0.48313 * *$ \\
\hline 8. & Avg. milk consumption & $0.40223 * *$ & 0.30894* \\
\hline 9. & Annual family income & $0.31823 *$ & $0.15786^{\mathrm{NS}}$ \\
\hline 10. & Annual family income from dairying & $0.62026 * *$ & $0.45012 * *$ \\
\hline 11. & Social participation & $0.77283 * *$ & $0.54204 * *$ \\
\hline 12. & Attitude towards dairy farming & $0.57965 * *$ & $0.54298 * *$ \\
\hline 13. & Economic motivation & $0.41188 * *$ & $0.21340 *$ \\
\hline 14. & Source of motivation for dairy communication & $0.83440 * *$ & $0.86407 * *$ \\
\hline 15. & Extension contact & $0.66125 * *$ & $0.37232 * *$ \\
\hline
\end{tabular}

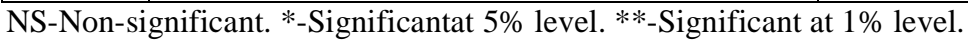

Table 2: Multiple Regression between Independent Utilization of Information

\begin{tabular}{|c|c|c|c|c|c|c|}
\hline \multirow[b]{2}{*}{ Sl. No. } & \multirow[b]{2}{*}{ Independent Variable } & \multirow[b]{2}{*}{$\begin{array}{l}\text { Variable } \\
\text { No. }\end{array}$} & \multicolumn{2}{|c|}{ Tribal } & \multicolumn{2}{|c|}{ Non-Tribal } \\
\hline & & & $\begin{array}{c}\text { Regression } \\
\text { Coefficient b } \\
\text { Value }\end{array}$ & $\begin{array}{c}\text { ' } t \text { ' Value for } \\
\text { B }\end{array}$ & $\begin{array}{c}\text { Regression } \\
\text { Coefficient B } \\
\text { Value }\end{array}$ & $\begin{array}{l}\text { 'T' Value } \\
\text { for b }\end{array}$ \\
\hline 1. & Age & $\mathrm{X}_{1}$ & 1.409 & 2.21 & -0.534 & -1.30 \\
\hline 2. & Family size & $\mathrm{X}_{2}$ & -0.383 & -0.19 & -1.053 & -0.61 \\
\hline 3. & Educational status & $X_{3}$ & 6.160 & 1.27 & 8.686 & 1.99 \\
\hline 4. & Herd size & $X_{4}$ & 4.412 & 0.74 & -4.869 & -1.48 \\
\hline 5. & Farm size & $\mathrm{X}_{5}$ & 0.337 & 0.14 & 2.372 & 1.57 \\
\hline 6. & Avg. milk prod. & $\mathrm{X}_{6}$ & 22.614 & 0.92 & 18.911 & 0.93 \\
\hline 7. & Avg. milk disposal & $\mathrm{X}_{7}$ & -30.152 & -0.97 & -14.052 & -0.39 \\
\hline 8. & Avg. milk consumption & $\mathrm{X}_{8}$ & -3.555 & -0.21 & -14.832 & -0.75 \\
\hline 9. & Annual family income & $\mathrm{X}_{9}$ & -0.000146 & -0.36 & -0.000608 & -1.60 \\
\hline 10. & $\begin{array}{l}\text { Annual family income } \\
\text { from dairying }\end{array}$ & $\mathrm{X}_{10}$ & 0 & 0 & -0.000302 & -0.07 \\
\hline 11. & Social participation & $\mathrm{X}_{11}$ & 7.087 & 0.52 & 2.593 & 0.34 \\
\hline 12. & $\begin{array}{l}\text { Attitude towards dairy } \\
\text { farming }\end{array}$ & $\mathrm{X}_{12}$ & 4.225 & 1.79 & 1.394 & 0.65 \\
\hline 13. & Economic motivation & $\mathrm{X}_{13}$ & 2.192 & 0.86 & 3.147 & 1.52 \\
\hline 14. & $\begin{array}{l}\text { Source of motivation for } \\
\text { dairy communication }\end{array}$ & $\mathrm{X}_{14}$ & $7.797 * *$ & 4.46 & $14.526 * *$ & 6.88 \\
\hline 15. & Extension contact & $\mathrm{X}_{15}$ & 3.025 & 1.03 & -2.0263 & -0.77 \\
\hline & & \multicolumn{3}{|c|}{$\mathrm{R}^{2}=0.859, ' \mathrm{~F}$ ' value for $\mathrm{R}=15.18 * *$} & $\begin{array}{l}\mathrm{R}^{2}=0.845 \\
\mathrm{R}=12.37 * *\end{array}$ & value for \\
\hline
\end{tabular}


